\title{
Parenting Patterns for Cadets in the New Normal Period of the Covid-19 Pandemic
}

\author{
Rina Haryani ${ }^{1}$, Ilham Ashari ${ }^{1}$, Avera Linarti ${ }^{1}$ \\ ${ }^{1}$ Human Resources Development Agency for Transportation, Barombong Maritime \\ Polytechnic, Indonesia
}

\begin{abstract}
This article discusses Parenting Patterns for Cadets and all things tied to parenting in the New Normal Period of the Covid-19 Pandemic. The new normal parenting pattern for Barombong Maritime Polytrvhnic cadets is the cadets' perception of parenting patterns based on three kinds of parenting patterns, namely authoritarian parenting, democratic parenting and permissive parenting, which have been adapted to Permanent Daily Activity (KHST) and Cadet Rules and Regulations (PERTIBTAR) the New Normal rules given to Barombong Maritime Polytechnic cadets. The cadet parenting pattern is the cadet's perception of the parenting pattern given to the cadets in the Barombong dormitory Polytechnic, based on the measurement of three kinds of parenting patterns, namely authoritarian parenting, democratic parenting and permissive parenting. cadets to be able to enter campus must be adjusted to the requirements of the Covid19 Task Force and the Barombong Maritime Polytechnic. The cadets who meet the requirements according to the provisions can enter the dormitory and take part in permanent daily activities (KHST). The daily activities of the cadets during this pandemic are arranged according to the health protocol so that a new Permanent Daily Activity (KHST) schedule is made that has been adapted to the conditions of the Pandemic, as well as Cadet Rules and Regulations (PERTIBTAR) with the current pandemic conditions, there have been additional rules for Cadet Rules And Regulations (PERTIBTAR) that existed previously.
\end{abstract}

Keywords: Parenting, Cadets, New Normal, Covid 19

Received: April 27, 2021

Revised: May 28, 2021

Accepted: June 16, 2021

\section{Introduction}

Parenting patterns for cadets are perceived as authoritarian parenting patterns using the power of caregivers to legitimize existing education and parenting regulations so that this pattern is considered unsuitable to be applied to the development of adolescents or early adulthood, where adolescents and early adults already have more mature abilities than childhood. Child abuse and the use of power to adolescents and early adults must be balanced with the rationale for implementing these regulations (Stewart-Brown, 2008; Guinote \& Vescio, 2010; Baharudin et al 2010).

Barombong Maritime Polytechnic cadets live in dormitories with several comprehensive care programs, this is in accordance with the opinion of Morrison et al (2005) that child care is the comprehensive care and education of children outside the home to complement the care and education that children receive from their families. Parenting programs are aimed at meeting a variety of needs.

Barombong Maritime Polytechnic cadets are on average in their late teens and into adulthood, so based on Baumrind's opinion, authoritarian parenting is not appropriate for cadets. The pattern of cadet care given by the caregivers at the Barombong Maritime Polytechnic is an attitude and behavior in caring for the cadets. Caregivers are like parents of cadets in the dormitory and other cadets as family members during the care period, all of which are important 
elements for the development of cadets in the dormitory. This can be referred to as parenting style or a form of cadet parenting.

There is an opinion from one of the alumni the alumni corps of the Barombong Maritime Polytechnic who said that when they carried out education and received care in 2010 the parenting pattern was regulated through PHST activities and the parenting pattern that was obtained at that time was perceived as authoritarian parenting, The authoritarian care they received in life after being outside the dormitory was very large, they became more independent and disciplined because of the implementation of PHST when they were still in the dormitory/campus, and until now they are still often carried away by the application of PHST in working activities on ships or when returning to school on land. Examples of the activities mentioned include getting up on time, being disciplined at work and being responsible for every mandate given, being mentally more mature, independent and more confident at work. From the opinion of the alumni, it can provide a little explanation that parenting is not always perceived as an authoritarian parenting pattern is not good, authoritarian parenting does not mean violence. Indeed, basically there is no one type of ideal parenting.

Caregivers can combine several types of parenting, according to the conditions of the cadets. For example, authoritarian parenting can be applied to cadets who have behavior problems or are related to disciplinary violations. Even though the parents of cadets do not have experience, they should still be given the right to express their opinion. Caregivers may provide input, including the consequences of the decisions to be taken, but the decision-making remains in the hands of the cadets. This can train cadets to be independent in making the right decisions, so they can be responsible for their decisions. This is further expected to increase the intelligence and self-regulated learning of cadets. In self-regulated learning, cadets learn to be responsible for their education and their own learning processes, such as awareness and evaluation of thinking processes, the right way, and motivating themselves continuously. Selfregulated learning emphasizes the autonomy and responsibility of students towards the learning process (Latipah, 2010; Kristiyani, 2016; Salman \& Nursalim, 2021).

A successful life in the era of industry 4.0 cannot only rely on intellectual intelligence, where a high level of intellectual intelligence is no longer the only human ability to survive and develop themselves. Ability to manage emotions, mature in attitude and not excessive in acting, as well as confidence in their competence. This must be realized in the care of cadets at the Barombong Maritime Polytechnic so that these abilities can be firmly embedded and can animate the behavior of cadets. To guide cadets to have competence, soft skills and be stable is not an easy thing, so serious efforts are needed from the entire Barombong Polytechnic academic community. These efforts are carried out through the implementation of permanent daily activities (KHST) in the dormitory, the application of Cadet Rules and Regulations and academic regulations, then it is hoped that cadets can animate education and parenting patterns in their daily lives and make cadets have independence, emotional maturity and responsibility for their learning process activities. well.

The outbreak of the Covid-19 pandemic that hit Indonesia also had an impact on the lives of cadets on campus, where the Permanent Daily Activity (KHST), Cadet Rules and Regulations (PERTIBTAR) rules were adjusted during this pandemic. Caregivers are expected to pay more attention to the health protocols that have been established so that cadets can be more independent and responsible for health, and the implementation of learning. Based on this, the researchers identified the types of parenting patterns perceived by cadets during this pandemic period, and their impact on self-regulated learning, with the title Research on the Effect of New Normal Parenting Patterns on Self-Regulated Learning in Barombong Maritime Polytechnic cadets. 


\section{Parenting}

Parenting is a pattern of interaction between children and parents during the child's care. In the parenting process, in addition to how parents treat children, it is also about how parents educate, guide, instill discipline, and protect children (Susanto \& Aman, 2016). With the hope that later they will become individuals who have maturity in accordance with the norms prevailing in society in general. As long as the cadets are in the same parental role, the cadet caregivers carry out their parenting duties, wherein the parent/mother caregiver educates, guides, instills discipline, and protects the cadets manifested by attitudes as parents towards their children. These attitudes include, how to help cadets to be able to carry out regular daily activities Permanent Daily Activity (KHST), when giving rewards or punishments, how caregivers show authority and also how caregivers pay attention and respond to their cadets. So the parenting pattern is a way for caregivers to carry out care for their cadets.

\section{Kinds of Parenting}

Parenting in three tendencies, namely authoritarian parenting, the characteristics are firm, like to punish, lack of affection, lack of sympathy. Parents like to force their children to obey their values, and try to shape the behavior of children according to the behavior patterns of parents, and tend to curb the desires of children. Parents do not encourage children to be independent, children's rights are very limited and have been entrusted with responsibilities that are too burdensome for children (Dewi \& Susilawati, 2016).

According to Stewrt \& Koch (1983) authoritarian parents have characteristics that are always rigid, like to punish, do not show feelings of affection and are not sympathetic. They always see children in terms of obedience to parental authority, tragically authoritarian parents have a tendency to give punishment, especially physical punishment. The effect of authoritarian parents generally shapes the behavior of children who are confused, easily irritated, with characteristics including fear, anxiety, aggressive and aloof, moody and sad. Children are unsympathetic, dissatisfied, easily suspicious, lack initiative, are easily nervous, hesitant, like to be rebellious, like to oppose the authority of their parents, may be timid or too obedient (Susanto, 2002: 27).

Democratic parenting, according to Susanto (2015) parents with democratic parenting are usually warm and close to their children, state clear standards for their children, apply and communicate rules strictly and clearly, do not like bad children, do not hesitate to apply punishment. within certain limits consistently if the child makes repeated mistakes, and gives rewards if he gets achievements and provides support if the child does constructive activities. The effects of democratic parents generally shape the behavior of children who are energetic and friendly with the characteristics of being independent, having high energy, being able to control themselves, being cheerful, friendly, easy to work with other people, their peers or more mature, having the ability to deal with problems. and cope with the possibility of pressure (stress).

Permissive parenting is a parenting pattern that tends to give freedom to children with very loose control, children are left on their own, as if spoiling children excessively, always obeying children's requests, and parents don't regulate much. Parents do not clearly communicate the rules to their children, do not consistently instill discipline, but are warm enough to their children (Susanto, 2015). According to Hurlock (2001) permissive parenting is characterized by lack of control, parents are loose and free, and little guidance is given to children. The effect of permissive parenting will make children who behave wildly without control, ignorant, children are free to act as they wish, communication is rare, children will be disobedient and against rules, lack self-confidence, lack self-control, tend to be aggressive, impulsive and have 
no goals. Likewise, it is the cause of immature, dependent and unhappy children, chaotic personality, always suspicious of others, and difficult to work with, has no sympathy for parents, unstable emotions, always filled with feelings of dissatisfaction. Hurlock (1974) parenting patterns for their children consist of four types which are bipolar, meaning in pairs and opposites), namely: (1) tolerant and intolerant; (2) permissive and strict; (3) let and get involved; (4) cold relationship and warm relationship.

According to Syaodih (1999) positive parenting in early childhood is based on: (1) parenting with the principle of intimacy, namely, based on affection, warmth, and closeness always exists between one another. Mothers will approach their children by displaying a motherly attitude when guiding them. Mother's feelings are not involved and are not affected even though they live it. In guiding requires not only maternal instinct but also requires a very high awareness. Overspending of affection can give the impression of pampering. Likewise, the relationship becomes cold, arid, lonely, because of a lack of love. What should be used as a benchmark by parents is affection on the basis of responsibility and demands responsibility as well. (2) Parenting with the principle of caring, namely, based on the principle of caring (attention, interest, sincerity). Attention is given to children about what is needed, what is felt, listening and answering questions fairly means according to the child's age. A natural personality development will be obtained by children, if parents show their concern by always providing guidance to their children. (3) Parenting with the principle of freedom, namely, based on the principle of freedom, children are given the freedom without hesitation to choose and express their opinions. In guiding their children, parents always stimulate their children to have a dialogue without hesitation, be directed, and accept freedom with a full sense of responsibility. The freedom given is not unlimited but there is still control. This means not freedom without a basis and grip, but freedom on the basis of provisions. As humans, we have duties and responsibilities to our creator, as a consequence of our attachment to the laws of life. (4) Parenting with the principle of independence, namely, initially parents do not hesitate to direct, encourage, get used to, so that children do it themselves. Gradually the child becomes trained / accustomed, over time the child will do it himself. The implementation of this pattern is not easy to take place well while in fact it is an ideal parenting pattern. Because they don't have the heart, often parents still help with what the child is doing, while in fact the child is still able to do it. (5) Parenting with the principle of discipline, namely, a parenting pattern that is closely related to the following rules. According to Abdullah (in Susanto, 2002) discipline is a set of planned activities or exercises needed to achieve certain goals (positive discipline). Discipline is a punishment for unwanted behavior (negative discipline). Its purpose is to prevent unwanted behavior, to help individuals understand what is needed to achieve goals and to encourage people to maintain and adhere to the practice or rules that have been developed. Guidance principles must be carried out in instilling discipline as something fundamental to children. It is an essential step in guidance, if the instillation of discipline in children by parents always takes place through good relationships. Furthermore, the child can introspect about why there is a violation, what to do, and what the consequences are for himself or for others. (6) Parenting with realistic principles, namely, reality-oriented parenting or the reality of life. Children are taught to be able to live by accepting things as they are, something according to their abilities, facilities with existing conditions. Parents are required to express something honestly, not looking for reasons to make children happy. (7) Parenting with the principle of stable emotions, namely, it is hoped that in parenting children, parents always do not show negative emotions (full of tension, angry, sad, anxious, quick to anger) and other attitudes As parents, we must continue to learn to be able to control our emotions, to be ready to face the diverse behaviors and desires of our children. 
Meanwhile, according to Lazarus et al (2016), the type of parenting style of parents towards their children is described as an attitude of neglecting, protecting excessively, having what one wants, accepting, warm, hostile, rejecting, and others.

Gottman \& DeClaire (1999) divides parenting styles into four styles, namely: (1) The parental style ignores, parents are accustomed to directly solving the child's problems or resolving all the child's pain, not first asking what the child feels., trying to avoid unpleasant feelings for children, children cannot automatically feel what they feel but parents teach that feeling, minimize / belittle children's sadness and children's problems, cover them up and throw them away to be forgotten or by distracting, parents feel afraid the child will be emotional and lose control. The consequences of this parental style of neglect are: they learn that their feelings are wrong, inappropriate or invalid, they may learn that "from there" there is something wrong with them because of the way they feel, they may have difficulty regulating emotions. they. (2) The style of parents disapproves, parents are conspicuous critical and unsympathetic, suspicious of children's emotional experiences, do not understand children but are more likely to pay attention to behavior around children's emotions, take advantage of trivial situations before determining action, fear emotions are difficult to control, children not being given the opportunity to experience their emotions and cope effectively leaves children unprepared for challenges. The consequences of a disapproving parental style are: they learn that their feelings are wrong, inappropriate or invalid, they may learn that "from there" there is something wrong with them because of the way they feel, they may have difficulty regulating emotions. -their emotions (same as ignoring type). (3) Laissez Faire parenting style (Latin, meaning let it go), empathetic parents (whatever is fine), let children express emotions as they please "our work is done", tend to be unskilled and unwilling to guide how to deal with negative emotions, little awareness how to help children to learn from emotional experiences, not sure what to teach, likes to accept children's reactions without giving, children cannot calm themselves/overcome emotions, do not provide guidelines for managing emotions, free children to release emotions with inappropriate emotional expressions/ free. The consequences of laissez faire parents are: children do not learn to regulate their emotions, children have difficulty concentrating, making friends, getting along with other children. (4) The style of emotional coach parents, in carrying out their role as emotional coaches requires interaction in five steps, namely: realizing their child's emotions; recognize those emotions as opportunities for intimacy and teaching; listen with empathy and affirm the child's feelings; help her child find the words to name the emotion she is experiencing; find boundaries while helping children solve problems at hand.

Parents with this style are able to accept the child's feelings and not ridicule and not belittle, guide the child through the world of emotions, go further than accepting and set boundaries for inappropriate behavior, teach children how to regulate feelings to find expressions. appropriate expressions, and solve problems, take the positive side of something we consider negative, give appreciation for the expression of children's emotions and react in good ways, encourage honesty in children's emotions, be able to stop harmful behavior and directing back to activities or expressions that are not harmful, do not protect children against unpleasant emotions so that children gain experience and how to manage them, parents do not immediately fix children's problems/problems, parents do not hesitate to show their emotions in front of children willing to apologize to the children when wrong.

Therefore, parents who are emotional coaches have advantages for their families, namely: (1) parents are consistently responsive to their children when feelings are still present at a low level of intensity. This means that emotions do not need to increase before the child gets the attention he is looking for. Over time, children will get the impression that their parents pay attention, understand, empathize in their lives. They do not have to vent their anger to get the attention of their parents. (2) If the child receives training from an early age, the child will be able to 
entertain himself and remain calm even though he is under mental pressure and this prevents wrong actions from happening. (3) Parents do not deny their emotions so as to reduce conflict, because there are boundaries and clear and consistent messages about daily behavior, so that being an emotional coach parent creates emotional bonds between children and parents become strong, therefore the child will be responsive to the requests of parents. Children see their parents as their allies, they want to please and they don't want to disappoint.

The consequences of the emotional coach parenting style on children are: children learn to trust their feelings, regulate their own emotions, solve their problems, have high self-esteem, study well, and get along with other people well.

From the understanding of parenting patterns and types of parenting above, in this study what is meant by cadet parenting patterns is the cadets' perception of the parenting pattern provided for cadets who are in the Barombong Maritime Polytechnic dormitory, based on measurements of three kinds of parenting patterns, namely authoritarian parenting, democratic parenting and permissive parenting.

\section{New Normal Parenting Pattern for Barombong Maritime Polytechnic cadets}

Since June 2, 2020, the Barombong Maritime Polytechnic, ordered cadets who are outside the campus to enter through a summons issued by the Head of the Academic Administration Section Number: SM502/41/ Barombong Maritime Polytechnic.B-2020 to Number: SM502/46/ Barombong Maritime Polytechnic. B-2020 dated May 19, 2020 Regarding the Call for Cadets to Enter Campus. There are different requirements for entering campus this time due to the pandemic situation experienced by the world, and South Sulawesi as an area where Large-Scale Social Restrictions have been imposed through the Decree of the Minister of Health of the Republic of Indonesia Number: HK.01.07/MENKES/257/2020 on December April 16, 2020 regarding the Determination of Large-Scale Social Restrictions in the Makassar City Region, South Sulawesi Province in the context of Handling the Corona virus disease 2019 (COVID-19). Every cadet who enters campus must follow the protocol from the South Sulawesi covid-19 cluster according to a letter from the Chair of the Prov Covid-19 Handling Acceleration Task Force. South Sulawesi on behalf of Mr. Eden Chandra Hayat Number: B/83/VI/2020 dated June 1, 2020 Regarding Notification, that every cadet who will come and serve, must have a negative result of the Covid-19 RT-PCR swab test from their respective regions of origin . Furthermore, cadets to be able to enter campus must be adjusted to the requirements of the Covid-19 Task Force and the Barombong Maritime Polytechnic. The cadets who meet the requirements according to the provisions can enter the dormitory and take part in permanent daily activities of Permanent Daily Activity (PERTIBTAR). The daily activities of the cadets during this pandemic are arranged according to the health protocol so that a new Permanent Daily Activity schedule is made that has been adapted to the conditions of the Pandemic, as well as Cadet Rules and Regulations (PERTIBTAR) with the current pandemic conditions, there have been additional rules for Cadet Rules and Regulations (PERTIBTAR) that existed previously. The Permanent Daily Activity and which are adapted to the conditions during the pandemic are the new normal rules for Barombong Maritime Polytechnic cadets

\section{Conclusion}

The new normal parenting pattern for Barombong Maritime Polytechnic Cadet Rules And Regulations (PERTIBTAR) cadets is the cadets' perception of parenting patterns based on three kinds of parenting patterns, namely authoritarian parenting, democratic parenting and permissive parenting, which have been adapted to Permanent Daily Activity and Cadet Rules 
(PERTIBTAR) And Regulations the New Normal rules given to Barombong Maritime Polytechnic cadets

\section{References}

Baharudin, R., Hong, C. Y., Lim, S. J., \& Zulkefly, N. S. (2010). Educational goals, parenting practices and adolescents' academic achievement. Asian Social Science, 6(12), 144.

Dewi, N. P. A. R., \& Susilawati, L. K. P. A. (2016). Hubungan antara kecenderungan pola asuh otoriter (authoritarian parenting style) dengan gejala perilaku agresif pada remaja. Jurnal Psikologi Udayana, 3(1), 108-116.

Gottman, J. M., \& DeClaire, J. (1999). Raising an emotionally intelligent child New York.

Guinote, A. E., \& Vescio, T. K. (2010). The social psychology of power. Guilford Press.

Hurlock, E. B. (1974). Personality Development. New Delhi : Hill Publishing Company.

Hurlock. E. B. (2001). Developmental psychology. Tata McGraw-Hill Education.

Kristiyani, T. (2020). Self-Regulated Learning: Konsep, Implikasi dan Tantangannya Bagi Siswa di Indonesia. Sanata Dharma University Press.

Latipah, E. (2010). Strategi self regulated learning dan prestasi belajar: kajian meta analisis. Jurnal psikologi, 37(1), 110-129.

Lazarus, R. S., Dodd, H. F., Majdandžić, M., De Vente, W., Morris, T., Byrow, Y., ... \& Hudson, J. L. (2016). The relationship between challenging parenting behaviour and childhood anxiety disorders. Journal of affective disorders, 190, 784-791.

Morrison Gutman, L., McLoyd, V. C., \& Tokoyawa, T. (2005). Financial strain, neighborhood stress, parenting behaviors, and adolescent adjustment in urban African American families. Journal of Research on Adolescence, 15(4), 425-449.

Salman, M., \& Nursalim, M. (2021). Studi Kepustakaan Tentang "Self Regulated Learning”. Jurnal BK UNESA, 12(1).

Stewart-Brown, S. (2008). Improving parenting: the why and the how. Archives of disease in childhood, 93(2), 102-104.

Susanto, A. (2015). Bimbingan \& Konseling di Taman Kanak-kanak. Jakarta: Prenadamedia.

Susanto, A. A. V., \& Aman, A. (2016). Pengaruh pola asuh orang tua, pergaulan teman sebaya, media televisi terhadap karakter siswa SMP. Harmoni Sosial: Jurnal Pendidikan IPS, 3(2), 105-111.

Syaodih, E. (1999). Pengasuhan Orang Tua dan Interaksi Teman Sebaya Dalam Pengembangan Program Bimbingan Perilaku. Jurnal Ilmu Pendidikan, 6. 